\title{
Youth gambling in Croatia - frequency of gambling and the occurrence of problem gambling ${ }^{1}$
}

\author{
Neven Ricijaš \\ Dora Dodig Hundrić \\ University of Zagreb, Faculty of Education and Rehabilitation Sciences, \\ Department of Behavioral Disorders
}

\begin{abstract}
Aleksandra Huić
University of Zagreb, Faculty of Humanities and Social Sciences, Department of

Psychology
\end{abstract}

Valentina Kranželić

University of Zagreb, Faculty of Education and Rehabilitation Sciences, Department of Behavioral Disorders

Abstract

The main aim of this study was to explore the frequency of gambling and gambling-related problems among Croatian high school students. The specific objectives have been to explore gender differences, and differences in the frequency and severity of gambling problems regarding grade/age and type of school program. The study included $n=2.702$ high school students from all for grades and all three types of high school programs (3- and 4-year vocational/professional schools, and grammar schools) from 7 cities (Zagreb, Osijek, Rijeka, Split, Vinkovci, Slavonski Brod and Koprivnica) with equal representation of boys $(n=1.330,49.2 \%)$ and girls $(n=1.372,50.8 \%)$. The respondents' mean age was Mage $=16.51$ (SDage=1.17).

The following instruments were used: Questionnaire on general socio-demographic data, Gambling activities questionnaire (Ricijaš, Dodig, Huić, \& Kranželić, 2011) and the Canadian Adolescent Gambling Inventory - CAGI (Tremblay, Stinchfield, Wiebe, \& Wynne, 2010).

Results show that the lifetime prevalence of gambling among Croatian high-school students is $72.9 \%$. The most prevalent games of chance are sports betting and lottery games, with sports betting being the most frequent of these activities. As much as $12.9 \%$ adolescents have already developed serious adverse gambling related consequences. Boys have significantly higher problem gambling rates than girls, while the effects of differences regarding the type of school and grade/age are relatively low.

The results provide important baseline data for future research, interventions design, and for the improvement of social policy and legislation.

1 The project was conducted as part of the "Youth Gambling in Croatia" study, conducted at the Faculty of Education and Rehabilitation Sciences of the University of Zagreb, and supported financially and organizationally by the Ministry of Science, Education and Sport, the Teacher Training and Education Agency, and the Croatian Lottery, Ltd. 
Keywords: gambling, sports betting, problem gambling, psychosocial problems, adolescents, youth gambling, high school students

\section{Introduction}

it is well known that adolescence is a developmental period that brings a greater risk of engaging in risk behaviors. The contemporary neuroscientific findings significantly contribute to the explanation of this adolescence-specific phenomenon's etiology. An increased propensity to take risks at the time of transition from childhood to adolescence is a result of changes in the part of the brain in charge of social and emotional functioning. These types of changes bring about an increase in reward seeking behavior, particularly in the presence of peers, which is brought on by the restructuring of the dopaminergic system (Steinberg, 2007; 2008; 2010). It is thus hardly surprising that both the research experience, as well as working with youths of that age confirm a greater prevalence of various risk behaviors, including gambling (Derevensky and Gilbeau, 2015). Furthermore, the current youths are growing up in a society that has, over the past several decades, seen dramatic changes due to the development of new information technologies which has been reflected in both the availability and the modes of gambling and games of chance. The games are more accessible and more varied. Taking into account the nature of games of chance, including the uncertainty of outcome, the fact that they are (like drugs and alcohol) forbidden to youths, and a strong monetary and physiological reward they bring, it is easy to assume that these games become an object of interest among the thrill-seeking adolescents.

Research directed at studying this interesting behavioral phenomenon indicates that adolescents not only engage in various gambling activities, but also do so in a problematic manner, which brings about a whole range of undesirable consequences. The results of studies conducted in the United States, Canada, and Australia, the countries with the longest tradition of youth gambling research, suggest that between 2 and $8 \%$ of youths display compulsive and/or problematic gambling patterns (Fisher, 1993; Winters, Stinchfield and Fulkerson, 1993; Shaffer, LaBrie, Scanlan and Cummings, 1994; Shaffer and Hall, 1996; Gupta and Derevensky, 1998; Derevensky and Gupta, 2000; Jacobs, 2000; Huang and Boyer, 2007; Welte, Barnes, Tidwell and Hoffman, 2008). Further, the most recent analysis of 44 studies of youth gambling (ages ranges from 10 to 24) across the world (Calado, Alexandre and Griffiths, 2016) found that between $0.2 \%$ and $12.3 \%$ of youths satisfy the criteria of problem gambling.

Given the geographic, social, and cultural context of contemporary Croatia, it is important to focus on findings from studies conducted in Europe. A Danish study $(n=2223)$ found that the rate of problem gambling among 11 - to 17 -year olds was $1.3 \%$ (Kristiansen and Jensen, 2014). That study utilized the South Oaks Gambling Screen (Lesieur and Blume, 1987), the revised version for adolescents, SOGS-RA (Winters, Stinchfield and Fulkerson, 1993). The same measurement instrument, on a Finnish sample of 5000 youths, found an identical proportion of young problem gamblers (Ilkas and Aho, 2006, in Calado, Alexandre and Griffiths, 2016), while a modified instrument based on the DSM-IV criteria (1996) for pathological gambling (DSM-IV-MR-J, Fisher, 2000) recognized $7.9 \%$ of youths who are at risk or have already developed gambling problems (Castren, Grainger, Lahti, Alho and Salonen, 2015). The SOGS-RA criteria for problem gambling are satisfied by $2.7 \%$ of youths in Iceland $(n=750)$ (Olason, Sigurdardottir and Smari, 2006). Several research studies on the 
same topic have been conducted in Norway, where the different measurement instruments found varying proportions of youths that have gambling-related problems. Johansson and Götestam (2003), using a sample of 3237 children and youths and applying the DSV-IV instrument, identified $1.76 \%$ of pathological gamblers and $3.46 \%$ of problem gamblers. Rossow and Molde (2006) used the SOGS-RA instrument and found a proportion of $2.5 \%$ young problem gamblers, while the study by Hanss et al. (2014) found that only $0.2 \%$ of youths manifest more serious gambling-related problems, as defined by the criteria of the Problem Gambling Severity Index - PGSI, by Ferris and Wynne (2001). The results of the Estonian national survey ( $n=2005)$ show that $75 \%$ of respondents had gambling experience, but that $3.4 \%$ satisfy the SOGS criteria of pathological gambling. Even though the age ranged from 15 to 74 , the authors concluded that the youths are at a greater risk for developing problems, and that they take up a greater than expected proportion of those who have developed gambling problems (Laansso, 2006, in Volberg, Gupta, Griffiths, Olason and Delfabbro, 2010). Two measurement instruments were used in a Lithuanian study ( $n=835)$ : the SOGS-RA recognized $5.2 \%$ of youths as problem gamblers, while the DSM-IV-MR-J recognized 4.2\% as such (Skokauskas, 2009). In Germany, Hurrelman, Schmidt and Kahnert (2003, in Volberg et al., 2010), with a sample of 5000 youths whose age ranged from 13 to 19 , found that $62 \%$ of them engaged in some sort of gambling in the previous year, and that $3 \%$ satisfied the DSM-IVMR-J criteria for problem gambling, with young men being at particular risk. A proportion of $4.3 \%$ of youths were found to be at risk in Switzerland, while 1.3\% had developed serious gambling-related problems (Tozzi, Akre, Fleury-Schubert and Suris, 2013). Somewhat higher proportions of young gamblers were found in Spain, where Becoña, Míguez and Vázquez (2001) identified 5.6\% of youths with developed gambling problems, using the SOGS-RA instrument. Great Britain follows closely: Griffiths and Wood (2007) among a representative sample found a rate of 3.5\% of problem gamblers. The studies in Romania applied the GA-20 (Gamblers Anonymous Twenty Questions) instrument and found that 6.8\% (Lupu, Onaca i Lupu, 2002), and 3.48\% (Lupu i Todirita, 2013) of youths satisfy the criteria for problem gambling. The research in Italy confirms significant levels of youths that are dealing with gambling-related problems: Villella et al. (2011) On a sample of 2853 youths, ages 13 to 20, Villella et al. (2011) found that $7 \%$ had already developed problems. The study by Colasante et al (2014), with a sample of 5930 youths found the same to have occurred among $5.9 \%$ of youths (both of these studies used the SOGS-RA instrument). The Czech national prevalence study, for the age group ranging from 15 to 24 , found that $7.4 \%$ were at risk of developing gambling problems (using the Lie/Bet scale), while the proportion among the population over the age of 24 was significantly lower, and ranged between 3.3 and 5.9\%, depending on the age group (Mravčík et al., 2014).

When it comes to the countries that are closer to Croatia in geographical and contextual matters, the data in Serbia (Serbian national lifestyle study) ${ }^{2}$ show that $3.7 \%$ of the population is at risk of developing gambling problems. When it comes to minors, we can refer to the ESPAD study from 2011 that found that $3.1 \%$ of students in Serbia gamble in a way that can potentially harm their psychosocial functioning (Molinaro et al., 2014). In Bosnia and Herzegovina, the research project that matched our own in methodology found that, in a sample of 1036 high-school students in Sarajevo and Tuzla, $69 \%$ of students had engaged in gambling at some point in their lives, with the most prevalent forms being instant lottery (41.9\%), Bosnia and Herzegovina National Lottery

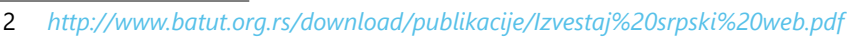


Sports Betting (36.1\%), sports betting establishments (34\%), and TV Bingo (29.5\%). Further, as many as $8.3 \%$ of them, by the criteria of the Canadian adolescent gambling questionnaire - CAGI (Tremblay, Stinchfield, Wiebe and Wynne, 2010), are exhibiting adverse psychosocial consequences of gambling (Bijedić, Kuralić-Čišić, Kovačević and Vardo, 2015).

These results indicate that the prevalence of problem gambling among youths varies from country to country. Moreover, it is often the case that findings differ within the same country. One of the reasons for such variation is undoubtedly the research methodology, i.e. the use of different measurement instruments and sampling methods, which makes direct comparisons of findings impossible. However, we should also take into account a significant impact of environmental factors, such as availability and accessibility of gambling, gambling regulations, and advertising of the games themselves. The contemporary theoretical models of problem gambling also accentuate the importance of availability, starting from the assumption that, in order for one to develop a gambling problem, the games of chance must first be available (Blaszczynski and Nower, 2002; Nower and Blaszczynski, 2004). In that sense, it is fair to assume that the countries with greater availability of games of chance would also be seeing greater rates of problem gamblers. Of course, this link is not linear and causal, as other factors need to be taken into account, but it does exist, as confirmed by various studies (Becona et al.., 1995, in Raylu and Oei, 2002; Productivity Commission, 1999; Campell and Lester, 1999; Ladouceur, Jacques, Ferland and Giroux, 1999).

This is particularly relevant for tackling the problem of gambling in Croatia, where the choice was made to take a liberal approach to organizing the games of chance, which was reflected in their availability, particularly when it comes to sports betting and slot machines. More precisely, based on the information provided by the Croatian Bureau of Statistics (2010) ${ }^{3}$, during the nineties there were approximately 350 venues/outlets that had permission for the sale and organizing of games of chance. The number grew to over 1.600 by 2009. Now, there are 15 casinos in Croatia, along with 234 slot machine clubs (with a total of 7.753 slot machines), and 4099 points that provide sports betting ${ }^{4}$. The last of these experienced the most growth, with the number of points of sale growing by 1.000 in the five years from 2010 to 2015. Furthermore, we should not neglect the fact that technological development has expanded the modes and opportunities for partaking in games of chance, so that most of these games can now be accessed online, from one's home, or even from self-service terminals that are available in many bars and cafes. All of these circumstances suggest that the real availability of games of chance is undoubtedly much higher than what can be gleaned from objective indicators.

With regard to the legal framework, the Games of Chance Act (NN 87/09, 35/13, 158/13, 41/14, 143/14; referred to as the Act in the remainder of the text) has regulated the market for games of chance, and the changes to the Act passed in 2010 have made them unavailable to anyone younger than 18. However, as will be seen in the remainder of this paper, in spite of this regulation, underage youths nevertheless manage to take part in gambling. This is certainly made possible by the above described availability of games of chance. However, when it comes to children and youths, we must not neglect the effects of gambling advertising, another area where Croatia's liberal approach to the matter can be observed. While there are significant restrictions on

3 The data were provided by the Croatian Bureau of Statistics for the specific needs of our research project.

4 These data were provided by the Ministry of Finance of the Republic of Croatia, in an official letter to dr. Neven Ricijas, the PI of the project, on June 16th 2016. 
advertising alcohol and tobacco (Electronic Media Act, 2009) forbidding any type of direct adverts, the legislature has chosen to only ban advertising of games of chance in media content directed explicitly at children (Games of Chance Act, NN 87/09, 35/13, 158/13, 41/14, 143/14), without any other standards. This approach is in contradiction with the recommendations of the leading experts in the field who, based on years-long experience and scientific research, suggest that the same rules apply to advertising of gambling, alcohol, and tobacco (Griffiths, 2005).

All that was stated above makes it clear that the indicators from other countries continually confirm a significant prevalence of problem gambling among youths. Additionally, Croatia is seeing a liberal approach to games of chance which places economic gain at its center and transfers the responsibility to the free will of the citizens. This approach has some serious shortcomings, particularly when it comes to youths, since it is the society's responsibility to ensure favorable conditions for growth and fulfilling the desired developmental outcomes for youths. These conditions have not been satisfied in Croatia when it comes to the protection of youths from this risky activity, which is corroborated by the findings of recent research in the country. The project entitled "Substance Abuse among the General Population in the Republic of Croatia: Research Report" (Glavak Tkalić and Miletić, 2012), found that $66.5 \%$ of young adults (15-24 years of age) in Croatia have at least once taken part in a game of chance, while $3.2 \%$ of them think that they had at some point in their life a gambling-related problem (in contrast to $1.5 \%$ among adults overall). The research conducted in the town of Virovitica (Koić i Medved, 2009) returned the result of $38.5 \%$ of young men in high schools who take part in games of chance, while the proportion was $44.9 \%$ among the high school students in the Bjelovar-Bilogora County (Puharić, Kudumija Sljepčević, Badrov and Petričević, 2016). Around $75 \%$ of high school students in Zagreb noted that they had gambled at least once in their lives, while 8 to $12 \%$ (depending on the measurement instrument that was used) displayed risky gambling patterns (Dodig i Ricijaš, 2011).

However, in spite of the data from individual studies, we have been lacking a systematic overview of the key indicators on gambling among Croatian high schoolers, such as the prevalence of particular forms of games of chance, the frequency of playing, and the rate of problem gambling. Providing data on all of these is the main aim of this paper. In spite of the descriptive nature of this aim, it nevertheless contributes to the future strategies for prevention and intervention, and it also allows for the testing of the hypothesis stated earlier, that the greater availability and accessibility of games of chance is tied to a greater frequency and higher rates of youth problem gambling. Given the high availability and accessibility of the sites where one may engage in games of chance, we expect that Croatian high school students will gamble more, and engage in problem gambling more frequently than their peers in European and other countries.

Additionally, foreign research has shown that there are some socio-demographic characteristics of adolescents that contribute to the risk factors for high school students' gambling, so the additional aim of this paper is to test the gender and age differences in the prevalence of problem gambling in the specific context of Croatia. We further aim to assess the differences across the three types of high school programs that are found in the Croatian school system.

The results of international studies suggest that young men gamble more often than young women do, and that they engage in those types of games that are more conducive to the 
development of serious gambling problems (Derevensky and Gilbeau, 2015; Desai, Maciejewski, Pantalon and Potenza, 2005; Donati, Chiesi and Primi, 2013; Welte, Barnes, Tidwell and Hoffman, 2009). We thus expected that the young men in our sample would gamble more often than the young women, and that they would report more serious consequences of gambling than young women would.

We have also wanted to test the existence of age differences in the frequency of gambling, and the psychosocial problems that appear in its wake. It is particularly important to test these differences with regard to the research findings that indicate that early involvement in games of chance is linked with a greater probability of problem gambling later in life, and a greater risk of developing gambling addiction as a grown-up (Carbonneau, Vitaro, Brendgen and Tremblay, 2015; Delfabbro, King and Griffiths, 2014; Rahman et al., 2012). However, neither international nor Croatian research provides systematic data on the age differences in adolescent gambling. Given that gambling is illegal in Croatia for anyone younger than 18 , it is possible to assume that the sites where games of chance are available would be less accessible to younger adolescents (e.g. high school freshmen) than to those in the final year of high school. Additionally, given that it takes some time to develop psychosocial problems brought on by gambling, we expect that the students in the final years of high school would be making up a greater proportion of the group of problem gamblers. However, given the lack of research into this topic, it is difficult to formulate more detailed hypotheses.

The Croatian research into other types of risk behaviors consistently show that the pupils in vocational high schools are more likely to engage in risky activities than the pupils in grammar schools (Ajduković, Ručević and Šincek, 2009; Kuzman, 2003). At the same time, as shown by both Croatian and international research, adolescent gambling often appears in parallel with other highrisk and delinquent behaviors (Ricijaš, Dodig Hundrić and Kranželić, 2015; Welte et al., 2009). We have thus expected that this study would show a similar trend, and that the high school students in vocational schools would report more involvement in gambling activities, and be involved in more risky gambling activities than their peers in grammar schools.

\section{Method}

\section{Sample}

The research was conducted on a convenience sample of 2702 high school students in seven Croatian cities ( $m=1.330,49.2 \% ; f=1.372,50.8 \%)$. The study included participants from all types of high school programs, from the first to the final years of study. Table 1 presents the distribution of participants by hometown, type of school, and the grade they are in. The respondents' age ranges from 14 to 21, with the average age being 16.51 (Mage=16.51, SDage=1.17).

Bigger cities, i.e. the regional centers (Zagreb, Split, Rijeka, and Osijek) were represented by two schools in each of the school types (grammar school, 4-year vocational school, 3-year vocational school). The study was administered in one class (approx. 30 students) in each of the generations, from the first grade to the last. The class was randomly selected. In smaller towns 
Neven Ricijaš, Dora Dodig Hundrić, Aleksandra Huić, Valentina Kranželić: Youth gambling in Croatia...

(Slavonski Brod, Vinkovci, and Koprivnica), one school per type was selected, and the classes were chosen the same way as above.

Table 1 Descriptive statistics, basic socio-demographic characteristics $(n=2.702)$

\begin{tabular}{|c|c|c|c|c|c|c|c|}
\hline $\begin{array}{l}\text { City } \\
\%\end{array}$ & $\begin{array}{c}\text { Zagreb } \\
16.5 \%\end{array}$ & $\begin{array}{c}\text { Split } \\
19.9 \%\end{array}$ & $\begin{array}{l}\text { Rijeka } \\
16.8 \%\end{array}$ & $\begin{array}{l}\text { Osijek } \\
18.8 \%\end{array}$ & $\begin{array}{c}\text { SI. Brod } \\
9.8 \%\end{array}$ & $\begin{array}{l}\text { Vinkovci } \\
8.9 \%\end{array}$ & $\begin{array}{c}\text { Koprivnica } \\
9.3 \%\end{array}$ \\
\hline $\begin{array}{c}\text { Type of school } \\
\%\end{array}$ & \multicolumn{2}{|c|}{$\begin{array}{c}\text { Vocational, 3-year } \\
23.4 \%\end{array}$} & \multicolumn{3}{|c|}{$\begin{array}{c}\text { Vocational, 4-year } \\
37.6 \%\end{array}$} & \multicolumn{2}{|c|}{$\begin{array}{c}\text { Grammar school } \\
39.0 \%\end{array}$} \\
\hline $\begin{array}{c}\text { Grade } \\
\%\end{array}$ & \multicolumn{2}{|c|}{$\begin{array}{c}1 \text { st } \\
28.4 \%\end{array}$} & $\begin{array}{l}2 n d \\
26.4 \%\end{array}$ & & $\begin{array}{c}3 r d \\
26.6 \%\end{array}$ & \multicolumn{2}{|c|}{$\begin{array}{c}\text { 4th } \\
16.6 \%\end{array}$} \\
\hline
\end{tabular}

The data show that the proportion of students in grammar schools (39.0\%) and 4-year vocational schools (37.6\%) is quite similar, while the proportion of students in 3-year vocational schools is expectedly lower at $23.4 \%$. The situation is similar with the grades: the first three grades are represented in similar proportions, while the proportion of students in the fourth grade is somewhat smaller.

By testing for the gender differences with regard to individual demographic criteria, we have found that there is a small difference with regard to age, with young men being somewhat older than young women (Mage_m=16.58; Mage_f $=16.45 ; t=2.807 ; p<.010$ ). The young women are more often enrolled in grammar schools $\left(\chi^{2}=123.59 ; p<.001\right)$, while there are no differences with regard to the grade they are in $\left(\chi^{2}=8.91 ; p>050\right)$.

\section{Instruments}

In the first step, we have used the The general socio-demographic information questionnaire in order to collect data about the key socio-demographic information such as sex, age, type of school, and the participants' grade.

Following that, we have used the Gambling activity questionnaire (Ricijaš, Dodig, Huić $\mathrm{i}$ Kranželić, 2011) which contains questions about the frequency of taking part in the six key (and in our society, most accessible) games of chance: sports betting, lotto, scratch cards, slot machines, electronic roulette, and betting on virtual races. The formal aspect of these games of chance is that they are offered by the licensed establishments for the territory of the Republic of Croatia, and are also illegal for minors. Online betting was not tested for in particular, since it represents only a modality of engagement, and not a type of game of chance. Informal modes of gambling, such as bets among friends or playing cards for money, were not examined, as the main interest in this study is to connect the formal social aspect with the prevalence of gambling and the development of psychosocial harm in youths.

The task for the respondents was to mark whether they had played any of the listed games of chance in their lives, and if they answered in the affirmative, to indicate how often they engage in it. The scores ranged from 0 to 5 , with the following interpretations: $0=$ never, $1=$ once a year or less, 2 =about once a month, $3=$ about once a week, $4=$ several times a week, $5=$ every day. 
The Canadian adolescent gambling questionnaire - CAGI (Tremblay, Stinchfield, Wiebe i Wynne, 2010) was then used to measure the intensity of the harmful psychosocial consequences of adolescent gambling. ${ }^{5}$

To be more precise, we used the GPSS (general problem severity subscale), which utilizes 9 claims to measure the general level of harmful psychosocial consequences, allowing us to place the adolescents in one of the following groups based on their score:

1) No gambling-related problems (i.e., green light): 0 and 1 point

2) Low to moderate severity of gambling-related problems (i.e., yellow light): 2 to 5 points

3) High severity of gambling-related problems (i.e., red light): 6 or more points

The respondents' task was to answer how often they had acted or felt a certain way, with the content of the items covering a spectrum of psychosocial consequences, from the psychological ones and the loss of control, to the social and financial ones. Some examples of items include "How often have you felt bad because of the way you gamble or bet?" $(0=$ never, $1=$ sometimes, $2=$ most of the time, $3=$ almost always) and "How often did you return the next day, trying to recover the money lost by gambling/betting?" ( $0=$ never, $1=$ one to three times, $2=$ four to six times, $3=$ seven or more times). The scale displays satisfactory metric characteristics in terms of internal consistency, so that Cronbach's Alpha for the whole sample is $\alpha=.849$, and by gender it is $\alpha \mathrm{m}=.834 ; \alpha f=.788$.

In order to implement the instrument in this study, we have sought and received the written approval of the authors. Given that the instrument was originally constructed in the English language, we have translated the items (another translation was made by an independent translator), conducted a back translation into English, and relayed the back translation to the authors for approval. After that, the application approval was granted.

\section{Procedure and research ethics}

The study was conducted between 2011 and 2013 on a sample of high school students in seven Croatian cities (Zagreb, Rijeka, Split, Koprivnica, Vinkovci, Slavonski Brod). The students filled in the questionnaire in groups, in their own classrooms. The survey was implemented in all the classrooms by a team of experts from the Faculty of Education and Rehabilitation Sciences and the Faculty of Humanities and Social Sciences of the University of Zagreb, with the help of final-year students from the MA program in social pedagogy.

The survey was pen and paper based, and filling in of the questionnaires lasted one school period (45 minutes). All the participants were verbally informed of the basic aim of the research, their participation was anonymous and voluntary, and they could also decide to not complete the questionnaire at any point. The study was conducted in line with the Ethical Code of Research Involving Children (Ajduković and Kolesarić, 2003), and was approved by the Ethical Board of the Faculty of Education and Rehabilitation Sciences of the University of Zagreb.

5 For more on the instrument and its metric characteristics, see Dodig (2013). 


\section{Methods of Data Analysis}

With the aim of gaining insight into the prevalence of gambling and its adverse psychosocial consequences we have conducted our analyses with the methods of descriptive statistics (response frequencies, means), and used the Friedman test (nonparametric equivalent to analysis of variance) and the Wilcoxon signed rank test to rank the frequency of engaging in particular types of games of chance. We used the Mann-Whitney U-test or the Kruskal-Wallis (nonparametric) test, and the $\chi^{2}$ test to determine the differences in the frequency of gambling with regard to the set independent variables (gender, age, type of school).

\section{Results}

By asking the students if they had ever played a particular game of chance in their entire life (lifetime prevalence) we have determined how many in our sample have gambled at least once in their life (Figure 1). We have found that nearly $3 / 4$ of high school students in our sample, $73 \%$ of them, have at least once tried a formal game of chance. The lifetime prevalence was also tested among those students that were underage at the time of the study (17 years old or younger), as the students who are of age are legally allowed to partake in games of chance. The results indicate that the fact that they are underage is not preventing Croatian high school students from taking part in games of chance. Moreover, in our sample of underage high school students, we find that just $19.7 \%$ of them have never played a game of chance.

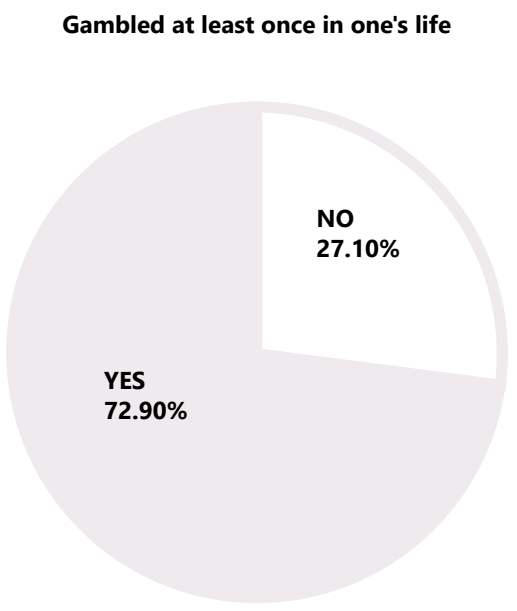

Figure 1 Graphical representation of the life-time prevalence of gambling in our sample $(n=2702)$

Figure 2 displays the results of the $\chi^{2}$ test we used to test for the gender differences in lifetime prevalence, and the graphical representation indicates that a greater proportion of girls had gambled at some point in their lives $\left(80 \% \vee 66 \% ; \chi^{2}=60.305 ; p<.001\right)$. One should bear in mind that this only tells us if someone took part in any of the games at any point in their lives (for example, if they played the lottery), but does not say anything about the frequency of gambling, which is particularly relevant when it comes to problem gambling. 


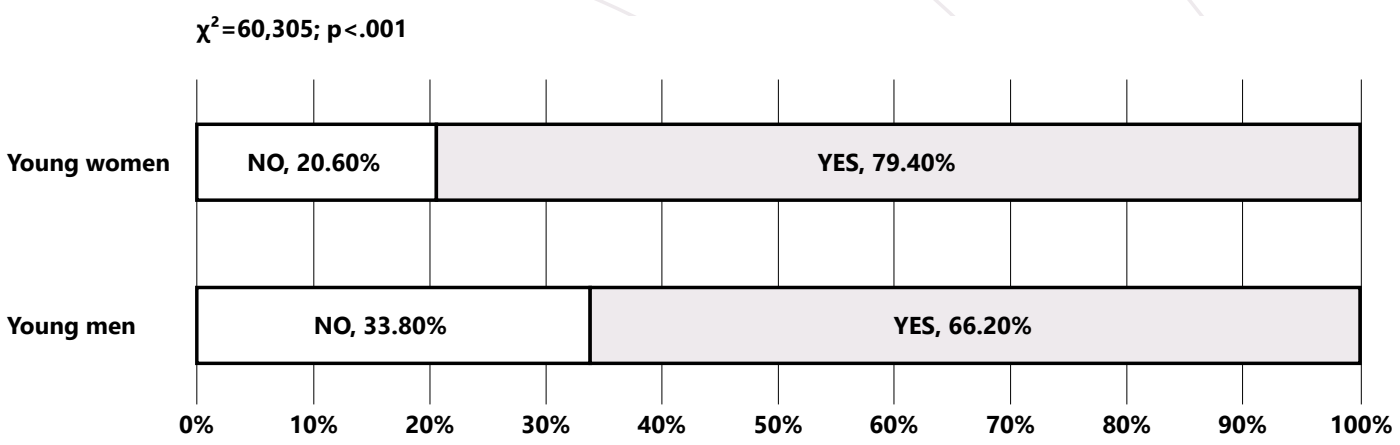

Figure 2 Graphical representation of the gender differences in the lifetime prevalence of gambling, $\chi^{2}$-test $(n=2$ 702)

Further, we asked our respondents about the lifetime prevalence of the various types of games of chance, and have displayed the results in Table 2. It allows us to notice that the greatest proportion of high school students have had the experience of betting on sports (around $40 \%$ of them have at least once placed a bet on sporting results), followed by scratch cards and lotto tickets. Some $20 \%$ of them have had the experience of using slot machines and betting on virtual races, while $10 \%$ had at least once played electronic roulette.

Table 2 Lifetime prevalence of various types of gambling

\begin{tabular}{|c|c|c|c|c|c|c|}
\cline { 2 - 7 } \multicolumn{1}{c|}{} & Sport betting & Lotto & Scratch cards & Slot machines & $\begin{array}{c}\text { Electronic } \\
\text { roulette }\end{array}$ & $\begin{array}{c}\text { Betting on virtual } \\
\text { races }\end{array}$ \\
\hline No & $59.3 \%$ & $66.3 \%$ & $53.2 \%$ & $78.8 \%$ & $90.5 \%$ & $79.4 \%$ \\
\hline Yes & $40.7 \%$ & $33.7 \%$ & $46.8 \%$ & $21.2 \%$ & $9.5 \%$ & $20.6 \%$ \\
\hline
\end{tabular}

However, along with the information on lifetime prevalence, we were particularly interested to learn about frequency. More precisely, we wanted to know to what extent our respondents took part in gambling activities, i.e. how many of them gamble occasionally, and how many gamble regularly. Based on the criteria proposed by Felsher, Derevensky and Gupta (2004), we have defined 'regular gambling' as engaging in the activity once a week or more. In terms of our questionnaire, this category encompasses all who replied with "once a week", "several times a week", and "every day". In that sense, and summarizing the results in Table 3, we find that betting on sports is the most common form of gambling, and that the frequency of engaging in it significantly differs from the frequency of engaging in any of the other types. Around $20 \%$ of Croatian high school students regularly place bets on sporting events, followed by slot machines, and betting on virtual races (around 7\%). Lotto and electronic roulette are the least common among those that regularly engage in games of chance, with a prevalence of around $3 \%$.

Table 3 Descriptive frequencies of high school students' gambling habits (\%) ( $n=2$ 702)

\begin{tabular}{|l|c|c|c|c|c|c|}
\hline Type of game & Never & $\begin{array}{c}\text { Once a year } \\
\text { or less }\end{array}$ & $\begin{array}{c}\text { Once a } \\
\text { month }\end{array}$ & Once a week & $\begin{array}{c}\text { Several times } \\
\text { a week }\end{array}$ & Every day \\
\hline Sports betting & 59.3 & 11.1 & $\mathbf{1 0 . 2}$ & $\mathbf{8 . 3}$ & $\mathbf{6 . 6}$ & $\mathbf{4 . 5}$ \\
\hline Lotto & 66.3 & 22.6 & $\mathbf{7 . 5}$ & $\mathbf{2 . 8}$ & $\mathbf{0 . 5}$ & $\mathbf{0 . 3}$ \\
\hline Scratch cards & 53.2 & 35.3 & $\mathbf{8 . 4}$ & $\mathbf{2 . 7}$ & $\mathbf{0 . 4}$ & $\mathbf{0 . 0}$ \\
\hline Slot machines & 75.8 & 9.8 & $\mathbf{7 . 4}$ & $\mathbf{3 . 6}$ & $\mathbf{2 . 2}$ & $\mathbf{1 . 3}$ \\
\hline
\end{tabular}


Neven Ricijaš, Dora Dodig Hundrić, Aleksandra Huić, Valentina Kranželić: Youth gambling in Croatia...

\begin{tabular}{|l|l|l|l|l|l|l|}
\hline Electronic roulette & 90.5 & 3.6 & $\mathbf{2 . 6}$ & $\mathbf{1 . 8}$ & $\mathbf{0 . 9}$ & $\mathbf{0 . 6}$ \\
\hline Betting on virtual races & 79.4 & 7.4 & $\mathbf{6 . 1}$ & $\mathbf{2 . 7}$ & $\mathbf{2 . 7}$ & $\mathbf{1 . 7}$ \\
\hline
\end{tabular}

Looking at the total frequency of gambling, we were curious about which games were played most often, and which ones were rarely engaged in. Table 4 provides the mean scores for the frequency of playing each of the types of games. In order to accurately rank the particular games, we calculated the Friedman test (nonparametric equivalent to analysis of variance), which has shown that the frequency of playing particular games is significantly different across types $\left(\chi^{2}=1440.758\right.$, $\mathrm{p}<.001)$. In order to exactly determine which of the types exhibit significant differences, we conducted a series of Wilcoxon tests (nonparametric equivalent of the t-test) which have shown significant differences between all types, except for lotto, slot machines, and betting on virtual races (see Table 4). The results indicate that betting on sports is the most common form of gambling on average, followed by scratch cards. Playing the lotto, slot machines, and betting on virtual races share the third place, while playing electronic roulette is the least common.

Table 4 The frequency ranking of all games, $t$-test for dependent samples (all) ( $n=2702)$

\begin{tabular}{|c|c|c|c|c|}
\hline Rank & Type of game & M & SD & Individual Wilcoxon rank tests \\
\hline 1 & Sports betting & 1.05 & 1.530 & $\begin{array}{c}Z_{\text {SB-SCR }}=-13.694^{* *} ; Z_{\text {SB-LO }}=-17.843^{* *} ; \\
Z_{\text {SB-SLOT }}=-19.782^{* *} ; Z_{\text {SK-VR }}=-21.537^{* *} ; Z_{\text {SK-ER }}=-26.565^{* *}\end{array}$ \\
\hline 2 & Scratch cards & 0.62 & 0.790 & $\begin{aligned} Z_{\text {SCR }-L O}= & -8.257^{* *} ; Z_{S C R-S L O T}=-6.194^{* *} ; \\
& Z_{S C R-V R}=-8.333^{\star *} ; \\
& Z_{S C R-E R}=-21.599^{\star *}\end{aligned}$ \\
\hline \multirow{3}{*}{3} & Lotto & 0.49 & 0.828 & $Z_{\text {LO- SLOT }}=-0.372 ; Z_{\text {LO-VR }}=2.289 ; Z_{\text {LO-ER }}=-15.187^{* *}$ \\
\hline & Slot machines & 0.50 & 1.061 & $Z_{\text {SLOT -VR }}=1.727 ; Z_{\text {SLOT -ER }}=-16.127^{* *}$ \\
\hline & Betting on virtual races & 0.47 & 1.098 & $Z_{V R-E R}=-13.199 * *$ \\
\hline 4 & Electronic roulette & 0.21 & 0.744 & \\
\hline
\end{tabular}

Legend: $M=$ mean $S D=$ standard deviation; $Z=$ value of the Wilcoxon test; $S B=$ sports betting, $S C R=s c r a t c h$ cards; $L O=l o t t e r y, S L O T=s l o t$ machine games, $V R=$ betting on virtual races; $E R=$ electronic roulette; ${ }^{* *} p<.001$

Table 5 presents the prevalence of adverse psychosocial consequences of gambling, utilizing the three categories and their corresponding traffic light metaphor, illustrating the severity of the problem: (1) green light (no problems); (2) yellow light (low to moderate level of severity of psychosocial consequences); and (3) red light (severe harmful psychosocial consequences). The insight into our results allows us to note that there is a relatively high prevalence of problems in the sample of Croatian high school students. More precisely, just $70 \%$ among them suffer no psychosocial problems related to gambling, $17 \%$ among them have low to moderately developed problems, and $13 \%$ satisfy the criteria of severe psychosocial gambling problems.

Table 5 Descriptive data on the prevalence of adverse psychosocial consequences of gambling, on the GPSS scale of the Canadian adolescent gambling scale - CAGl; for all respondents $(n=2702)$

\begin{tabular}{|c|c|c|c|c|}
\hline & & Green light & Yellow light & Red light \\
\hline \multirow{2}{*}{$\begin{array}{c}\text { GPSS - categorization of severity of psychosocial problems } \\
\text { related to gambling }\end{array}$} & $\mathbf{N}^{*}$ & 1.844 & 458 & 340 \\
\hline & $\%$ & 69.8 & 17.3 & 12.9 \\
\hline
\end{tabular}

Legend: $N=$ absolute number; ${ }^{*}$ note, the responses are missing for 60 participants; $\%=$ relative frequency, percentage 


\section{Gender differences}

In order to test for gender differences in the frequency of gambling, we have conducted a Mann-Whitney U-test on all six types of games, and the results of the test, along with the response frequencies (gambling prevalence for young men and women) are presented in Table 6. The results show that when it comes to lottery games (lotto and scratch cards), there are no gender differences, and both young men and women relatively rarely engage in this type of gambling.

We do, however, find significant effects of gender on all other games of chance, with boys engaging in them more often, with the effect of the difference $(r)$ highest for betting on sports $(r=.52)$. We may see that as many as $36.6 \%$ of the young men frequently place bets on sporting results, while the same is found only among $2.7 \%$ of the girls. Furthermore, $13.3 \%$ of young men regularly place bets on virtual races, and $12.7 \%$ of them regularly play slot machines. Electronic roulette is played regularly by $6.3 \%$ of the young men in our sample. The proportion of young women playing any of these regularly is negligible.

Table 6 Gender differences in the frequency of gambling among high school students - the Mann-Whitney U-test ( $n=2$ 702)

\begin{tabular}{|c|c|c|c|c|c|c|c|c|c|c|c|}
\hline \multirow[b]{2}{*}{$\begin{array}{l}\text { Type of } \\
\text { game }\end{array}$} & \multirow[b]{2}{*}{ Gender } & \multicolumn{6}{|c|}{ Gambling frequency (\%) } & \multicolumn{4}{|c|}{ Mann-Whitney U-test } \\
\hline & & Never & $\begin{array}{c}\text { Once a } \\
\text { year or } \\
\text { less }\end{array}$ & $\begin{array}{l}\text { Once a } \\
\text { month }\end{array}$ & $\begin{array}{c}\text { Once } \\
a \\
\text { week }\end{array}$ & $\begin{array}{c}\text { Several } \\
\text { times a } \\
\text { week }\end{array}$ & $\begin{array}{l}\text { Every } \\
\text { day }\end{array}$ & RANK & MW U & $\mathbf{p}$ & $\mathbf{r}$ \\
\hline \multirow{2}{*}{$\begin{array}{l}\text { Sports } \\
\text { betting }\end{array}$} & M & 34.4 & 12.3 & 16.7 & 15.3 & 12.4 & 8.9 & 1726.57 & \multirow{2}{*}{413538.0} & \multirow{2}{*}{$<.001$} & \multirow{2}{*}{.52} \\
\hline & $\mathbf{F}$ & 83.5 & 9.8 & 3.9 & 1.5 & 0.9 & 0.3 & 987.91 & & & \\
\hline \multirow{2}{*}{ Lotto } & $\mathbf{M}$ & 68.0 & 18.3 & 8.6 & 3.8 & 0.8 & 0.5 & 1343.36 & \multirow{2}{*}{901558.5} & \multirow{2}{*}{$>.050$} & \\
\hline & $\mathbf{F}$ & 64.6 & 26.9 & 6.4 & 1.8 & 0.2 & 0.1 & 1359.39 & & & \\
\hline \multirow{2}{*}{$\begin{array}{l}\text { Scratch } \\
\text { cards }\end{array}$} & M & 55.3 & 31.1 & 9.7 & 3.1 & 0.8 & 0.1 & 1339.20 & \multirow{2}{*}{896017.5} & \multirow{2}{*}{$>.050$} & \\
\hline & $\mathbf{F}$ & 51.1 & 39.4 & 7.1 & 2.3 & 0.1 & I & 1363.43 & & & \\
\hline \multirow{2}{*}{$\begin{array}{l}\text { Slot } \\
\text { machines }\end{array}$} & $\mathbf{M}$ & 63.8 & 12.1 & 11.5 & 6.4 & 4.1 & 2.2 & 1523.90 & \multirow{2}{*}{683084.0} & \multirow{2}{*}{$<.001$} & \multirow{2}{*}{.28} \\
\hline & $\mathbf{F}$ & 87.4 & 7.7 & 3.4 & 0.8 & 0.4 & 0.4 & 1184.37 & & & \\
\hline \multirow{2}{*}{$\begin{array}{l}\text { Electronic } \\
\text { roulette }\end{array}$} & $\mathbf{M}$ & 82.8 & 6.2 & 4.7 & 3.5 & 1.6 & 1.2 & 1456.15 & \multirow{2}{*}{773201.5} & \multirow{2}{*}{$<.001$} & \multirow{2}{*}{.25} \\
\hline & $\mathbf{F}$ & 98.0 & 1.1 & 0.6 & 0.1 & 0.3 & I & 1250.06 & & & \\
\hline \multirow{2}{*}{$\begin{array}{l}\text { Betting on } \\
\text { virtual races }\end{array}$} & M & 63.8 & 11.8 & 10.9 & 5.2 & 5.1 & 3.2 & 1565.14 & \multirow{2}{*}{628234.0} & \multirow{2}{*}{$<.001$} & \multirow{2}{*}{.37} \\
\hline & $\mathbf{F}$ & 94.5 & 3.1 & 1.5 & 0.3 & 0.4 & 0.4 & 1144.40 & & & \\
\hline
\end{tabular}

Legend: M=young men; F=young women; MW U=results of the Mann-Whitney test, $p=$ significance; $r=$ effect size; bold letters mark the statistically significant differences.

We ranked the average frequencies of gambling separately for the men and women in the sample, and used the Friedman test to do so. We have also conducted a post-hoc test to compute the final ranking (Tables 7 and 8). The first glance already suggests that there is a different structure of games with regard to the mean frequency ranking. Among the young men in our sample, we find that not only do they gamble more, but are also engaged in the games with highly addictive potential - sports betting, betting on virtual races, and slot machines. The lottery games take the third and fourth places, with electronic roulette in the fifth spot. 
Neven Ricijaš, Dora Dodig Hundrić, Aleksandra Huić, Valentina Kranželić: Youth gambling in Croatia...

Table 7 Ranking the frequency of playing all of the types of games, among young men ( $n=1$ 330)

\begin{tabular}{|c|c|c|c|c|}
\hline Rank & Type of game & $\mathbf{M}$ & SD & Individual Wilcoxon rank tests \\
\hline 1 & Sports betting & 1.86 & 1.711 & $\begin{array}{c}Z_{\text {SB-VR }}=-19.656^{* *} ; Z_{\text {SB-SLOT }}=-19.746^{* *} ; Z_{\text {SB-SCR }}=-21.628^{* *} ; \\
Z_{\text {SB-LO }}=-22.542^{\star *} ; Z_{\text {SB-ER }}=-23.836^{\star *}\end{array}$ \\
\hline \multirow{2}{*}{2} & Betting on virtual races & 0.85 & 1.379 & $\begin{array}{l}Z_{\text {VR- SLOT }}=-1.111 ; Z_{\text {VR-SCR }}=-5.159^{\star *} ; \\
Z_{\text {VR-LO }}=-7.984^{* *} ; Z_{\text {VR-ER }}=-12.415^{* *}\end{array}$ \\
\hline & Slot machines & 0.81 & 1.300 & $\begin{array}{c}Z_{\text {SLOT-SCR }}=-5.203^{* *} ; Z_{\text {SLTT-LO }}=-7.356^{* *} \\
Z_{\text {SLOT -ER }}=-12.908^{* *}\end{array}$ \\
\hline 3 & Scratch cards & 0.63 & 0.847 & $Z_{\text {SCR-LO }}=-4.550^{* *} ; Z_{\text {SCR-ER }}=-8.515^{* *}$ \\
\hline 4 & Lotto & 0.53 & 0.920 & $Z_{\text {LO-ER }}=-4.614^{* *}$ \\
\hline 5 & Electronic roulette & 0.39 & 0.987 & \\
\hline
\end{tabular}

Legend: $M=$ mean $S D=$ standard deviation; $Z=$ value of the Wilcoxon test; $S B=$ sports betting, $S C R=$ instant lottery; $L O=l o t t e r y, S L O T=s l o t$ machine games, $V R=$ betting on virtual races; $E R=$ electronic roulette; ${ }^{* *} p<.001$

The trends are completely different among the young women in our sample (Table 8). Not only do they gamble far less than their male peers, but are also most likely to engage in the games with a significantly lower addictive potential - lotto and scratch cards. Betting on sports, which took first place among the young men, only comes in third among the women, with a mean value of 0.28 . Slot machines are in the fourth place, followed by betting on virtual races and electronic roulette that is exceptionally rarely engaged in by girls.

Table 8 Ranking the frequency of playing all of the types of games, among young women $(n=1$ 372)

\begin{tabular}{|c|c|c|c|c|}
\hline Rank & Type of game & $\mathbf{M}$ & SD & Individual Wilcoxon rank tests \\
\hline 1 & Sports betting & 0.61 & 0.731 & $\begin{array}{c}Z_{\mathrm{LL}-\mathrm{LO}}=-7.360^{* *} ; Z_{\mathrm{IL}-\mathrm{SB}}=-13.616^{* *} ; Z_{\mathrm{LL}-\mathrm{MACH}}=-16.593^{* *} ; \\
Z_{\mathrm{IL}-\mathrm{VR}}=-20.336^{* *} ; Z_{\mathrm{IL}-\mathrm{ER}}=-22.620^{* *}\end{array}$ \\
\hline \multirow[t]{2}{*}{2} & Betting on virtual races & 0.46 & 0.726 & $\begin{aligned} Z_{\text {LO-SB }}=-8.365^{* *} ; Z_{\text {LO-MAC }} H=-11.371^{* *} ; Z_{\text {LO-VR }}=-15.935^{* *} ; \\
Z_{\text {LO-ER }}=-18.550\end{aligned}$ \\
\hline & Slot machines & 0.28 & 0.737 & $Z_{\text {SB-MACH }}=-3.435^{* *} ; Z_{\text {SB-VR }}=-8.656^{* *} ; Z_{\text {SB-ER }}=-11.872^{\star *}$ \\
\hline 3 & Scratch cards & 0.20 & 0.731 & $Z_{\text {MACH-VR }}=-5.841^{* *} ; Z_{\text {MACH-ER }}=-10.413^{* *}$ \\
\hline 4 & Lotto & 0.10 & 0.504 & $Z_{\text {VR-ER }}=-4.484^{\star \star}$ \\
\hline 5 & Electronic roulette & 0.04 & 0.294 & \\
\hline
\end{tabular}

Legend: $M=$ mean $S D=$ standard deviation; $Z=$ value of the Wilcoxon test; $S B=$ sports betting, $I L=$ instant lottery; $L O=l o t t e r y, M A C H=$ machine games, VR=betting on virtual races; $E R=$ electronic roulette; ${ }^{* *} p<.001$

These results make it clear that boys gamble more often and engage in games of chance with a significantly greater frequency. We can thus assume that they dominantly make up the group of youths with severe gambling-related problems. We tested this hypothesis with a $\chi^{2}$-test (Table 9$)$ and found it confirmed $\left(\chi^{2}=543.27 ; p<.001\right)$. Only $50 \%$ of young men satisfy the "green light" criteria, i.e. have no adverse gambling consequences. Furthermore, $27 \%$ of them fall in the "yellow category" of low to moderate severity of psychosocial problems, and as much as $23 \%$ satisfy the criteria of the "red light group", i.e. their everyday lives are severely disrupted by the adverse effects of gambling. 
Table 9 Gender differences in the categorization of the development of adverse psychosocial gambling consequences

\begin{tabular}{|c|c|c|c|c|c|c|}
\hline \multicolumn{2}{|c|}{$\begin{array}{l}\text { GPSS - categorization of the development of adverse } \\
\text { psychosocial gambling consequences }\end{array}$} & \multirow{2}{*}{$\begin{array}{c}\begin{array}{c}\text { Green } \\
\text { light }\end{array} \\
646\end{array}$} & \multirow{2}{*}{$\begin{array}{c}\begin{array}{c}\text { Yellow } \\
\text { light }\end{array} \\
356\end{array}$} & \multirow{2}{*}{$\begin{array}{c}\text { Red light } \\
312\end{array}$} & $x^{2}$ & $\mathbf{p}$ \\
\hline & $\mathbf{N}$ & & & & \multirow{4}{*}{543.27} & \multirow{4}{*}{$<.001$} \\
\hline & $\%$ & 49.2 & 27.1 & 23.7 & & \\
\hline \multirow{2}{*}{ Young women } & $\mathbf{N}$ & 1.198 & 102 & 28 & & \\
\hline & $\%$ & 90.2 & 7.7 & 2.1 & & \\
\hline
\end{tabular}

While the prevalence of adverse gambling effects among girls is significantly different, it is by no means negligible. Around $10 \%$ of the girls in our sample are at some risk, as $8 \%$ of them satisfy the "yellow light" criteria and $2 \%$ belong to the "red light" category and exhibit severe adverse gambling consequences.

\section{Age differences}

Given the high correlation of grade and age among high school students $(r=.894 ; p<.001)$, i.e. the fact that these two variables share nearly $80 \%$ of joint variance, we have decided to test the differences in the frequency of gambling across age groups by using the students' grade as an independent variable. This approach is further useful as it allows us to consider developmental characteristics of peer groups. All third grade students should be more similar to one another, regardless of whether they are 16 or 17 , than the students of the same age in different grades. We conducted a Kruskal-Wallis test to determine the differences in age, and then individual MannWhitney tests where the significant differences were found.

The results are presented separately for boys and girls (Table 10). Among the young women, the differences are only confirmed when it comes to betting on sports, with students in the first year of high school having far less experience betting than those in the final years. Among the young men, we have found differences across three games (betting on sports, scratch cards, and electronic roulette). The effects are the greatest when it comes to playing electronic roulette $\left(K V \chi^{2}=46.64 ; p<.001\right)$, so that the students in the final year of high school play this game more often than the ones in lower grades. Other differences are statistically significant, but the effects are substantively small.

Table 10 The differences in the frequency of gambling with regard to age/grade, separately for the young men $(n=1330)$ and women $(n=1372)$ in the sample - the Kruskal-Wallis test

\begin{tabular}{|c|c|c|c|c|c|c|c|}
\hline \multicolumn{2}{|c|}{ Sex } & \multicolumn{3}{|c|}{ Young men } & \multicolumn{3}{|c|}{ Young women } \\
\hline Type of game & Grade & MR & $K W \chi^{2}$ & MWU & MR & $K W \chi^{2}$ & MWU \\
\hline \multirow{4}{*}{ Sports betting } & 1st & 604.41 & \multirow{4}{*}{$15.378^{*}$} & \multirow{4}{*}{$\begin{array}{c}\text { 2nd }>1 \mathbf{s t}^{*} \\
\text { 3rd,4th>1st* }\end{array}$} & 630.24 & \multirow{4}{*}{$30.24^{* *}$} & \multirow{4}{*}{$2 \mathrm{nd}, 3 \mathrm{rd}, 4 \mathrm{th}>1 \mathrm{st}^{* *}$} \\
\hline & 2nd & 701.86 & & & 700.49 & & \\
\hline & $3 r d$ & 658.30 & & & 692.49 & & \\
\hline & 4th & 702.84 & & & 733.84 & & \\
\hline
\end{tabular}


Neven Ricijaš, Dora Dodig Hundrić, Aleksandra Huić, Valentina Kranželić: Youth gambling in Croatia...

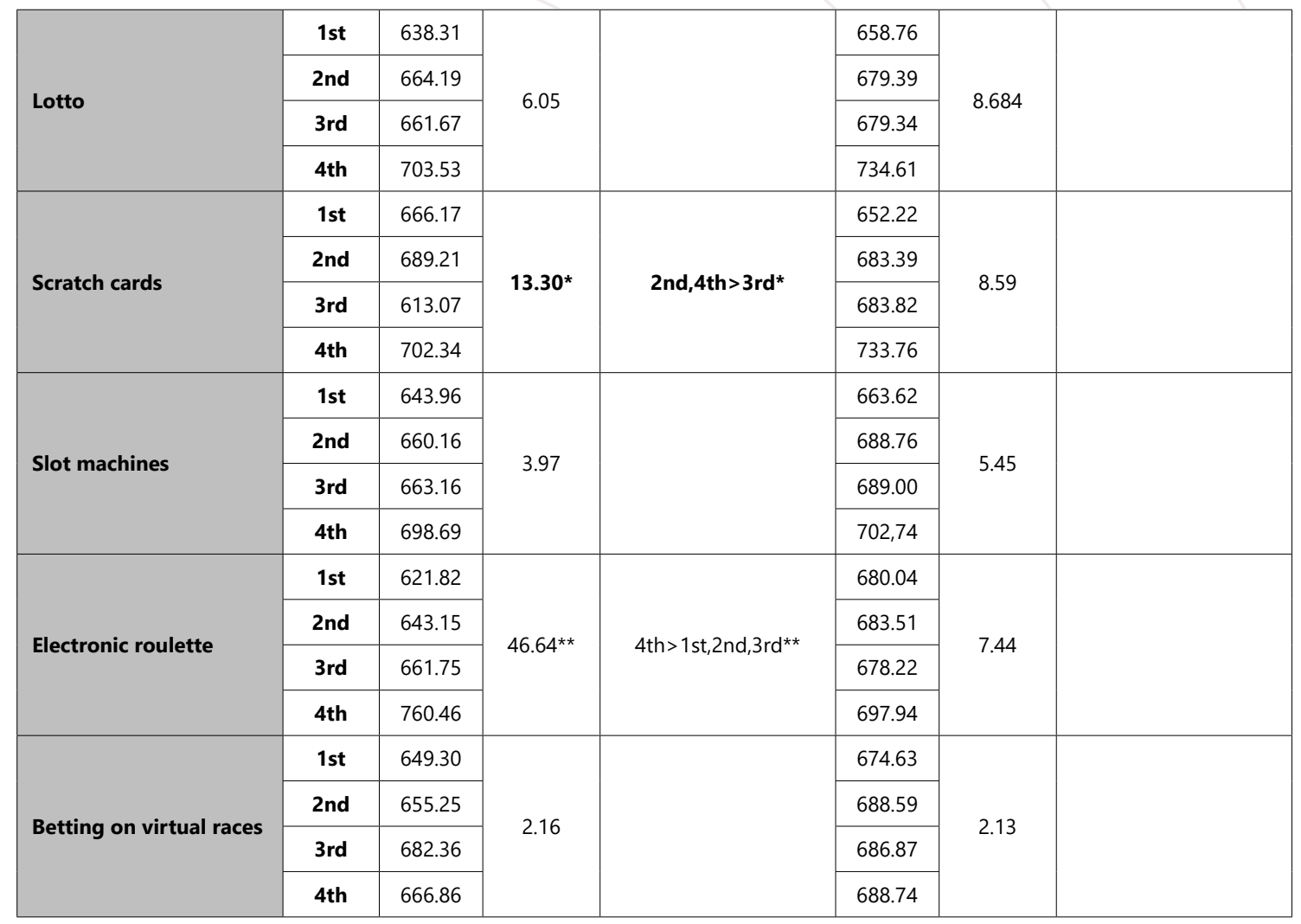

Legend: $M R=$ mean rank; $K W \chi^{2}=$ Kruskal-Wallis chi-squared; $M W U=$ Mann-Whitney U-test; ${ }^{*} p<.010 ;{ }^{* *} p<.001$

Logically, we also wanted to know if there are any differences in the extent to which the gambling problems are expressed with regard to age/grade, which we tested using the $\chi^{2}$-test (Table 11). The results are quite worrying, particularly for the young men, where there are no differences with regard to age/grade. A high prevalence of adverse psychosocial gambling consequences is obviously present in all grades/age groups. Between 50 and $60 \%$ of boys, regardless of the grade they are in, feel some sort of adverse gambling consequences.

Table 11 The difference in the extent of harmful psychosocial consequences of gambling (GPSS) with regard to age/grade, separately for the young men ( $n=1330)$ and young women $(n=1372)$ in the sample $-\chi^{2}$-test

\begin{tabular}{|c|c|c|c|c|c|c|}
\hline \multicolumn{7}{|c|}{ GPSS categorization with regard to grade/age } \\
\hline & & $\begin{array}{c}\text { Green } \\
\text { light }\end{array}$ & $\begin{array}{c}\text { Yellow } \\
\text { light }\end{array}$ & Red light & $x^{2}$ & $\mathbf{p}$ \\
\hline \multicolumn{7}{|l|}{ Young men } \\
\hline \multirow{2}{*}{ 1st grade } & $\mathbf{N}$ & 184 & 86 & 79 & \multirow{8}{*}{8.79} & \multirow{8}{*}{$>.050$} \\
\hline & $\%$ & 52.7 & 24.6 & 22.6 & & \\
\hline \multirow{2}{*}{ 2nd grade } & $\mathbf{N}$ & 178 & 96 & 77 & & \\
\hline & $\%$ & 50.7 & 27.4 & 21.9 & & \\
\hline \multirow{2}{*}{ 3rd grade } & $\mathbf{N}$ & 188 & 101 & 88 & & \\
\hline & $\%$ & 49.9 & 6.8 & 23.3 & & \\
\hline \multirow{2}{*}{ 4th grade } & $\mathbf{N}$ & 96 & 70 & 67 & & \\
\hline & $\%$ & 41.2 & 30.0 & 28.8 & & \\
\hline
\end{tabular}


Criminology \& Social Integration Journal Vol. 24 No. 22016

\begin{tabular}{|c|c|c|c|c|c|c|}
\hline Young wom & & & & & & \\
\hline \multirow{2}{*}{ 1st grade } & $\mathbf{N}$ & 369 & 19 & 8 & \multirow{8}{*}{11.89} & \multirow{8}{*}{$>.050$} \\
\hline & $\%$ & 93.2 & 4.8 & 2.0 & & \\
\hline \multirow{2}{*}{ 2nd grade } & $\mathbf{N}$ & 298 & 35 & 11 & & \\
\hline & $\%$ & 86.6 & 10.2 & 3.2 & & \\
\hline \multirow{2}{*}{ 3rd grade } & $\mathbf{N}$ & 287 & 27 & 5 & & \\
\hline & $\%$ & 90.0 & $8 . .5$ & 1.6 & & \\
\hline \multirow{2}{*}{ 4th grade } & $\mathbf{N}$ & 241 & 21 & 3 & & \\
\hline & $\%$ & 90.9 & 7.9 & 1.1 & & \\
\hline
\end{tabular}

\section{Differences with regard to type of high school attended}

In line with the previous results, we have also tested the significance of the differences in the frequency of gambling and the differences in the extent to which adverse gambling consequences are experienced, with regard to the type of school the respondents are attending. The results are presented in tables 12 and 13.

Table 12 Differences in the frequency of gambling with regard to the type of school, reported separately for boys ( $n=1330)$ and girls $(n=1372)$ - the Kruskal-Wallis test

\begin{tabular}{|c|c|c|c|c|c|c|c|}
\hline \multicolumn{2}{|c|}{ Sex } & \multicolumn{3}{|c|}{ Young men } & \multicolumn{3}{|c|}{ Young women } \\
\hline Type of game & $\begin{array}{l}\text { Type of } \\
\text { school }\end{array}$ & MR & $K W \chi^{2}$ & MWU & MR & $k W \chi^{2}$ & MWU \\
\hline \multirow{3}{*}{ Sports betting } & $3 y-v$ & 653.67 & \multirow{3}{*}{$23.12^{* *}$} & \multirow{3}{*}{$4 y-V>G^{* *}$} & 654.61 & \multirow{3}{*}{5.91} & \\
\hline & $4 y-V$ & 717.69 & & & 683.13 & & \\
\hline & G & 599.88 & & & 700.47 & & \\
\hline \multirow{3}{*}{ Lotto } & $3 y-V$ & 635.44 & \multirow{3}{*}{8.88} & & 580.46 & \multirow{3}{*}{$32.44^{* *}$} & \multirow{3}{*}{$4 y-V, G>3 S^{* *}$} \\
\hline & $4 y-V$ & 694.56 & & & 692.18 & & \\
\hline & G & 652.75 & & & 721.60 & & \\
\hline \multirow{3}{*}{ Scratch cards } & $3 y-v$ & 621.54 & \multirow{3}{*}{8.88} & & 597.51 & \multirow{3}{*}{$20.10^{\star *}$} & \multirow{3}{*}{$\begin{array}{c}4 y-V>3 y-V^{*} \\
G>3 S^{* *}\end{array}$} \\
\hline & $4 y-V$ & 682.49 & & & 691.68 & & \\
\hline & G & 684.77 & & & 715.68 & & \\
\hline \multirow{3}{*}{ Slot machines } & $3 y-v$ & 687.93 & \multirow{3}{*}{$29.21^{* *}$} & \multirow{3}{*}{$3 y-V, 4 y-V>G^{* *}$} & 664.34 & \multirow{3}{*}{2.859} & \\
\hline & $4 y-V$ & 701.83 & & & 690.12 & & \\
\hline & G & 588.76 & & & 692.20 & & \\
\hline \multirow{3}{*}{$\begin{array}{l}\text { Electronic } \\
\text { roulette }\end{array}$} & $3 y-v$ & 647.72 & \multirow{3}{*}{$13.95^{*}$} & \multirow{3}{*}{$3 y-V, 4 y-V>G^{*}$} & 683.64 & \multirow{3}{*}{0.60} & \\
\hline & $4 y-V$ & 695.35 & & & 689.19 & & \\
\hline & G & 639.13 & & & 685.74 & & \\
\hline \multirow{3}{*}{$\begin{array}{l}\text { Betting on } \\
\text { virtual races }\end{array}$} & $3 y-v$ & 683.87 & \multirow{3}{*}{$22.23^{* *}$} & \multirow{3}{*}{$3 y-V, 4 y-V>G^{* *}$} & 684.92 & \multirow{3}{*}{0.25} & \\
\hline & $4 y-V$ & 697.88 & & & 689.53 & & \\
\hline & G & 598.75 & & & 685.05 & & \\
\hline
\end{tabular}

Legend: $3 Y$-V = 3-year vocational high school; $4 Y-V=4$-year vocational school; $G=$ grammar school; $M R=$ mean rank; $K W \chi^{2}=K r u s k a l$ Wallis chi-squared; MWU = Mann-Whitney U-test; ${ }^{*} p<010 ;{ }^{* *} p<001$

Table 12 indicates that there is a difference between boys and girls. The only differences that appear among the girls concern the lottery games, so that the students in the 3-year vocational 
Neven Ricijaš, Dora Dodig Hundrić, Aleksandra Huić, Valentina Kranželić: Youth gambling in Croatia...

schools have far less experience playing the lotto and scratch cards than the young women in grammar schools and 4-year vocational schools. The differences are significant on all the highrisk games among the young men in our sample, as the grammar school students are less likely to gamble, and the effects of the differences are greatest when it comes to playing slot machines $\left(K V \chi^{2}=29.21 ; p<.001\right)$.

Table 13 The differences in the extent to which adverse psychosocial gambling consequences (GPSS) are found among the students, with regard to the type of high school attended, separately for boys $(n=1330)$ and girls $(n=1372)-\chi^{2}$-test

\begin{tabular}{|c|c|c|c|c|c|c|}
\hline \multicolumn{7}{|c|}{ GPSS with regard to the type of school } \\
\hline & & Green light & Yellow light & Red light & $x^{2}$ & $\mathbf{p}$ \\
\hline \multicolumn{7}{|l|}{ Young men } \\
\hline \multirow{2}{*}{3 -year vocational schools } & $\mathrm{N}$ & 181 & 107 & 90 & \multirow{6}{*}{19.06} & \multirow{6}{*}{$<.010$} \\
\hline & $\%$ & 47.9 & 28.3 & 23.8 & & \\
\hline \multirow{2}{*}{ 4-year vocational schools } & $\mathrm{N}$ & 249 & 159 & 155 & & \\
\hline & $\%$ & 44.2 & 28.2 & 27.5 & & \\
\hline \multirow{2}{*}{ Grammar schools } & $\mathrm{N}$ & 216 & 90 & 67 & & \\
\hline & $\%$ & 57.9 & 24.1 & 18.0 & & \\
\hline \multicolumn{7}{|l|}{ Young women } \\
\hline \multirow{2}{*}{3 -year vocational schools } & $\mathrm{N}$ & 221 & 18 & 8 & \multirow{6}{*}{2.94} & \multirow{6}{*}{$>.050$} \\
\hline & $\%$ & 89.5 & 7.3 & 3.2 & & \\
\hline \multirow{2}{*}{ 4-year vocational schools } & $\mathrm{N}$ & 382 & 37 & 9 & & \\
\hline & $\%$ & 89.3 & 8.6 & 2.1 & & \\
\hline \multirow{2}{*}{ Grammar schools } & $\mathrm{N}$ & 595 & 47 & 11 & & \\
\hline & $\%$ & 91.1 & 7.2 & 1.1 & & \\
\hline
\end{tabular}

Among the girls, there are no differences in the extent of adverse psychosocial gambling consequences (Table 13), while the boys in vocational schools have developed more adverse gambling consequences (23-28\%) compared to those in grammar schools (18\%). Though the effects of these differences are not substantively large $\left(X^{2}=19.06 ; p<.010\right)$. It should also be noted that the prevalence of adverse consequences is very high among the young men, regardless of the grade they are in, or the type of school they attend.

\section{Discussion}

The presented results make it clear that gambling, though formally and legally only intended for adults, is an activity that the youths in Croatia regularly engage in. As many as $72.9 \%$ of them have engaged in some form of formal game of chance, which supports the claim of availability and accessibility of such games. When we talk about youths, we are particularly focusing on the element of accessibility as differentiated from availability. Gambling may be available in our society, in the sense of there being establishments where such activities are organized, but they should not (as foreseen in the legislation) be accessible to youths. As this is not the case, it is only reasonable to assume that the regulations are not being implemented. 
The frequency of engaging in specific types of games of chance is particularly important to gain greater insight into the problem of youth gambling habits. Our results show that the greatest proportion of youths in our sample has experience of taking part in lottery and betting on sports. These results were expected: lottery is often considered harmless due to its characteristics, and the research continually confirms its prevalence across all age groups (Glavak Tkalić and Miletić, 2012). Betting on sports is a gambling activity that is exceptionally popular in Croatian society and which is (due to its connection to sporting events) particularly attractive and interesting to youths. Furthermore, betting on sports is the most common game of chance, as $20 \%$ of high school students regularly (once a week or more) place bets on the results of sporting events. However, we know from practical experience that a feature of this game of chance is the underestimation of the risks it brings. More precisely, it is considered harmless, often not even thought of as gambling at all, even as all the research points to the opposite. For example, other Croatian studies show that adolescent who regularly bet on sports make up the majority of the high risk adolescents (those with severe gambling related problems). Moreover, betting on sports is correlated with the manifestation of other risk behaviors (Dodig, 2013; Ricijaš, Dodig Hundrić and Kranželić, 2015).

Around $20 \%$ of high school students have experience with playing slot machines, and about $10 \%$ of them have tried electronic roulette. These games of chance are far less prevalent than betting on sports, and are relatively rarely engaged in by our respondents. However, even these figures should be considered alarming, as we are talking about a young population engaging in activities with a very high addictive potential. Griffiths (1999) notes that, due to the high frequency of events, the short interval between placing a stake and payout, the experience of nearly winning, and the potential for winning a very large amount of money with a relatively minimal stake, these games are particularly risky for developing gambling problems. Furthermore, we should not lose sight of the fact that these games of chance are being played in specialized clubs or casinos, and which means that the market is suffering from a serious problem of not enforcing the law. These places are also considered high-risk for involving youths in other unacceptable behaviors, such as substance abuse and delinquency.

Our results confirm yet again that adolescent gambling, as many other behaviors during adolescence, appears on a continuum of frequency, from complete non-engagement, to experimentation, and to regular use. This last extreme often produces serious consequences, and significant problems in psychosocial functioning. While the prevalence of problem gambling among European youths is found to be between 1 and $8 \%$, our survey suggests that the proportion of high school students in Croatia who are feeling serious adverse psychosocial gambling consequences is as high as $12.9 \%$. It is difficult to directly compare our results with those of the other studies, given that we have used a relatively new measurement instrument which is only now seeing more uptake in international research. However, the results that are currently available, from the application of the CAGI on a sample of Canadian high school students, suggest that there are $1.3 \%$ of youths $(n=2374$, ages 12 to 18$)$ who have developed severe gambling-related problems, a proportion significantly lower than the one we have found in Croatia. It is fair to assume that some of the difference may be ascribed to the methodological specificities of this research, particularly when it comes to representativeness and age range in the samples, but the difference between the two rates nevertheless remains stark. In that sense, the environmental factors must also be taken into 
account. Primarily, this refers to the greater accessibility of gambling and a lack of implementation of the legal age for gambling, but also the extent of advertising and a general acceptance of gambling (particularly in the case of betting on sports). Comparison with the data collected in the neighboring Bosnia and Herzegovina supports this assertion: the availability and accessibility of gambling is similar there, and the methodology is parallel to the one we used here. In that study, a significant portion (around 8\%) of youths in Sarajevo and Tuzla were found to suffer from adverse gambling consequences (Bijedić, Kuralić-Čišić, Kovačević and Vardo, 2015).

If we focus on the subsample of boys, the results become alarming. The study has found that the young men gamble with more intensity than their female peers, and that their gambling preferences are significantly different. Betting on sports is the preferred gambling activity for boys (mean value of 1.86), while it only comes third with girls (mean value of 0.28 ). Conversely, the girls' top two preferences for engaging in gambling, lotto and scratch cards, are less likely to be conducive to the development of gambling problems. For example, research by Sproston, Erens, and Orford (2010) found that the prevalence of problematic gambling among those who only played the lottery is only $0.1 \%$. Of course, such a risk should not be neglected when it comes to youths, but it is incomparably small in comparison with the risk from betting on sports or slot machines. As expected, the young men make up a greater portion of those respondents who have developed problems. The proportion of girls in "red light" group is $2.1 \%$, while $23.7 \%$ of all boys fall into that category. Additionally, around $27 \%$ of boys in our sample manifest a middle level of gambling-related problems ("yellow light"), pushing the proportion of boys for whom gambling causes moderate or severe harm to $50 \%$. The findings of gender differences are in line with much of international research that confirms this trend with almost no exceptions (National Research Council, 1999; Desai, Maciejewski, Pantalon and Potenza, 2005; Stuhldreher, Stuhldreher and Forrest, 2007; Shead, Derevensky and Gupta, 2010). If we connect these results with those concerning the whole sample, it becomes clear that this is where the similarities stop. The proportion of youths in Croatia, and particularly boys, for whom this risky activity disrupts personal, familial, educational and academic functioning is much greater than was the case in the international studies.

It is well known that, when it comes to involvement in risky behaviors, high school students are often differentiated by the type of school they attend (for more, see Ricijaš, Dodig Hundrić and Kranželić, 2015). At-risk youth group is made up of those that are having difficulties in school (Ajduković, Ručević i Šincek, 2009), and we also know that students in vocational schools are consuming more of alcohol and tobacco (Kuzman, 2003). For this reason we have expected that grammar school students would gamble less frequently and less problematically. Our expectation was confirmed, but the difference between the groups was narrower than expected. When it comes to the young men in high school, those attending 3-year vocational schools tend to participate in more of the games with highly addictive potential, and they make up a somewhat larger proportion of those exhibiting more severe psychosocial problems. However, as the effects of these differences are relatively low, we can generally conclude that the young men tend to gamble frequently, regardless of the type of school they attend.

Similar was found with regard to the differences in age/grade, which is particularly worrying. We had assumed that the younger students would engage in gambling less frequently, and that they would display less severe adverse psychosocial consequences of gambling. However, we 
have not found major differences across the age groups/grades, and the prevalence of problem gambling was similar across the age groups. These findings suggest that high school students (mostly boys) start gambling even before they commence high school, that they engage in this activity with great intensity, and that their gambling turns very quickly from social gambling to high-risk/problem gambling. These findings are particularly worrying as the literature has found that an early onset of gambling is a strong risk factor for continuing to gamble as an adult and developing a gambling addiction. The nonexistence of significant age differences also speaks in favor of a significant effect of environmental factors and the social climate the young people are growing up in, and which is strongly contributing to their engagement in games of chance and development of problem gambling, regardless of academic success, potential professional direction, and even the stage of adolescence.

This paper presents the first systematic study of prevalence of gambling and gambling-related problems among Croatian youths in both the regional urban centers and the smaller towns. Even though this sample is not representative of all high school students in Croatia, which is this study's key shortcoming, we have managed to achieve representativeness within cities. Future work ought to be based on a nationally representative sample, or should at least include students from smaller towns and other parts of the country. However, as our data on the high level of engagement of high school students in gambling activities coincide with the findings of other studies in Croatia (Glavak Tkalić and Miletić, 2012; Koić and Medved, 2009; Puharić, Kudumija Sljepčević, Badrov and Petričević, 2016), and knowing that the high-school age students from the small towns and villages are attending school in bigger towns, we believe that the data from a nationally representative sample would not significantly diverge from our findings.

The findings concerning the differences based on gender and age as well as the types of high schools contribute to the expansion of our knowledge, both locally and internationally, concerning the risk factors of problem gambling among youths. Apart from these findings, other work published in Croatia thus far focused primarily on the contribution of various personality characteristics, attitudes and behaviors to the explanation of the development of youth gambling, and on gaining insight into the correlates of youth problem gambling (Dodig, 2013; Ricijaš, Dodig Hundrić and Kranželić, 2015; Ricijaš, Dodig Hundrić and Huić, 2016). Future research should include a broader social context that the young people find themselves in, and should survey the parents and the teachers of adolescents concerning their role in enabling and supporting gambling among the youth, a topic that is underrepresented in both Croatian and international research.

\section{Conclusion}

Our findings concerning the prevalence of gambling, particularly betting on sports, among mostly underage boys, are alarming, and confirm the theoretical claims concerning the relation between the availability and liberalization of the gambling market and the higher rates of problem gambling. Additionally, our results provide a basis for developing high-quality social policy, strategies of public health provision, and interventions aimed at children and youths, as well as providing a basis for further scholarly work. Our findings on the differences in terms of age and gender, and in terms of type of high school a student is attending are all suggesting that the 
adverse psychosocial consequences are mostly affecting young men, regardless of their academic success, the type of school, or developmental age. Further, our findings contribute to the national and international corps of knowledge in this subject area.

The Republic of Croatia should undoubtedly follow the example of many European countries that are trying to provide an adequate response to this growing problem. However, what differentiates us is the extent to which the problem is pronounced, something that should be made clear at all levels. Problem gambling disrupts the young person's functioning within the family, the school, as well as hindering the youth's personal and social functioning. It thus makes it more difficult for the expected developmental outcomes to be achieved, which has consequences on a personal level, the family level, but also presents a cost to the state itself. In other words, the professional and scholarly efforts of professionals that work with children will have a very limited effect if the society does not begin to perceive youth gambling as a risk behavior, and if the market for games of chance remains so poorly regulated. The challenge that the society should embrace is that of combining our care for children and youths, as well as other vulnerable groups, with the financial interests of the state and the entrepreneurs.

\section{References}

Ajduković, M., Kolesarić, V. (Ur.) (2003): Etički kodeks istraživanja s djecom [Ethical Code for Research With Children]. Zagreb: Državni zavod za zaštitu obitelji, materinstva i mladeži.

Ajduković, M., Ručević, S., Šincek, D. (2009): Istraživanje rasprostranjenosti rizičnog i delinkventnog ponašanja djece i mladih u urbanim sredinama - dodatni poticaj za ciljanu prevenciju [Examination of distribution of risky and delinquent behavior among urban children and youth - additional incentive for target prevention]. Dijete i društvo, 10 (1/2), 27-47.

Becoña, E., Míguez, M. C., Vázquez, F. (2001): El juego problema en los estudiantes de Enseñanza Secundaria. Psicothema. 13. 551-556.

Bijedić, M., Kuralić-Čišić, L., Kovačević, R., Vardo, E. (2015): Obilježja kockanja srednjoškolaca u Sarajevu i Tuzli - izvještaj o rezultatima istraživanja [The characteristics of gambling among high schools pupils in Sarajevo and Tuzla - a research report], Edukacijskorehabilitacijski fakultet Sveučilišta u Tuzli, Tuzla.

Blaszczynski, A., Nower, L. (2002): A pathways model of problem and pathological gambling. Addiction. 97 (5), 487-499.

Calado, F., Alexandre, J., Griffiths, M.D. (2016): Prevalence of Adolescent Problem Gambling: A systematic Review of Recent Research. Journal of Gambling Studies. doi:10.1007/ s10899-016-9627-5

Campell, F., Lester, D. (1999): The Impact of gambling opportunities on compulsive gambling. Journal of Social Psychology. 139 (1), 126-127.

Carbonneau, R., Vitaro, F., Brendgen, M., Tremblay, R. E. (2015): Variety of gambling activities from adolescence to age 30 and association with gambling problems: a 15-year longitudinal study of a general population sample. Addiction. 110 (12), 1985-1993. 
Castren, S., Grainger, M., Lahti, T., Alho, H., Salonen, A.H. (2015): At-risk and problem gambling among adolescence: a convenience sample of first-year junior high school students in Finland. Substance Abuse Treatment, Prevention and Policy. 10, 9. DOI 10.1186/ s13011-015-0003-8

Colasante, E., Gori, M., Bastiani, L., Scalese, M., Siciliano, V., Molinaro, S. (2014): Italian Adolescent Gambling Behavior: Psychometric Evaluation of south Oaks Gambling Screen: Revised for Adolescents (SOGS-RA) among a sample of Italian students. Journal of Gambling Studies. 30 (4), 789-801.

Delfabbro, P., King, D., Griffiths, M. D. (2014): From adolescent to adult gambling: An analysis of longitudinal gambling patterns in South Australia. Journal of Gambling Studies. 30 (3), 547-563.

Derevensky, J., Gilbeau, L. (2015): Adolescent gambling: Twenty-five years of research. Canadian Journal of Addiction/Le Journal Canadien d'Addiction. 6, 4-12.

Derevensky, J.L., Gupta, R. (2000): Prevalence estimates of adolescent gambling: A comparison of the SOGS-RA, DSM-IV-J, and the GA. 20 Questions. Journal of Gambling Studies. $16,227-251$.

Desai, R.A., Maciejewski, P.K., Pantalon, M.V., Potenza, M.N. (2005): Gender differences in adolescent gambling. Annals of Clinical Psychiatry. 17 (4), 249-258.

Dijagnostički i statistički priručnik za duševne poremećaje: DSM-IV- međunarodna verzija s MKB šiframa [Diagnostic and statistical manual for mental disorders: DSM-IVinternational version with ICD codes] (1996): Jastrebarsko: Naklada Slap.

Dodig, D. (2013): Assessment challenges and determinants of adolescents' adverse psychosocial consequences of gambling. Kriminologija i socijalna integracija. 21 (2), 15-29.

Dodig, D., Ricijaš, N. (2011): Obilježja kockanja zagrebačkih adolescenata [Gambling of adolescents in Zagreb]. Ljetopis socijalnog rada. 18 (1), 103-125.

Donati, M. A., Chiesi, F., Primi, C. (2013): A model to explain at-risk/problem gambling among male and female adolescents: gender similarities and differences. Journal of Adolescence. 36 (1), 129-137.

Felsher, J.R., Derevensky, J.L., Gupta, R. (2004): Lottery Playing Amongst Youth: Implications for Prevention and Social Policy. Journal of Gambling Studies. 20 (2), 127-153.

Ferris, J., Wynne, H. (2001): The Canadian problem gambling index: Final report. Submitted for the Canadian Centre on Substance Abuse. https://www.problemgambling.ca/EN/ Documents/Problem GamblingSeverityIndex.pdf (15.5.2016.)

Fisher, S. (2000): Developing the DSM-IV-DSM-IV Criteria to Identify Adolescent Problem Gambling in Non-Clinical Populations. Journal of Gambling Studies. 16 (2,. 253-273.

Fisher, S. (1993): Gambling and pathological gambling in adolescents. Journal of Gambling Studies. 9 (3), 277-288.

Glavak Tkalić, R., Miletić, G.M. (2012): Igranje igara na sreću u općoj populaciji Republike Hrvatske: Istraživačko izvješće [Playing games of chance in the general population of the Republic of Croatia. A research report]. Zagreb: Institut društvenih znanosti Ivo Pilar.

Griffiths, M. D. (1999): The psychology of the near miss (revisited). British Journal of Psychology. 90, 441-445. 
Griffiths, M.D. (2005): Does advertising of gambling increase gambling addiction? International Journal of Mental Health and Addiction. 3 (2), 15-25.

Griffiths, M. D., Wood, R. T. A. (2007): Adolescent Internet gambling: Preliminary results of a national survey. Education and Health. 25, 23-27.

Gupta, R., Derevensky, J.L. (1998): Adolescent gambling behavior: A prevalence study and examination of the correlates associated with excessive gambling. Journal of Gambling Studies. 14, 319-345.

Hanss, D., Mentzoni, R. A., Blaszczynski, A., Molde, H., Torsheim, T., Pallesen, S. (2014): Prevalence and correlates of problem gambling in a representative sample of Norwegian 17-year-olds. Journal of Gambling Studies, http://link.springer.com/article/10.1007/ s10899-014-9455-4/fulltext.html (Retrieved 7.7.2016.)

Huang, J. H., Boyer, R. (2007): Epidemiology of youth gambling problems in Canada: A national prevalence study. Canadian Journal of Psychiatry. 52, 657-665.

Jacobs, D.F. (2000): Juvenile gambling in North America: An analysis of long term trends and future prospects. Journal of Gambling Studies. 16 (2/3), 119-152.

Johansson, A., Götestam, K. G. (2003): Gambling and problematic gambling with money among Norwegian youth (12-18 years). Nordic Journal of Psychiatry. 57, 317-321.

Koić, E., Medved, B. (2009): Stavovi mladih o kockanju [Youth attitudes towards gambling]. Hrvatski časopis za javno zdravstvo. 5, (17).

Kristiansen, S. G., Jensen, S. M. (2014): Prevalence and correlates of problematic gambling among Danish adolescents. International Journal of Social Welfare. 23, 89-99.

Kuzman, M. (2003): Ovisnička ponašanja u učenika u Hrvatskoj i Europi [Addictive behaviors in students in Croatia and Europe]. Paediatria Croatica. 47 (1), 173-184.

Ladouceur, R., Jacques, C., Ferland, F., Giroux, I. (1999): Prevalence of problem gambling: a replication study 7 years later. Canadian Journal of Psychiatry. 44 (8), 802-804.

Lesieur, H.R., Blume, S.B. (1987): The South Oaks Gambling Screen (SOGS): a new instrument for the identification of pathological gamblers. The American Journal of Psychiatry, 144 (9), 1184-1192.

Lupu, V., Onaca, E., Lupu, D. (2002): The prevalence of pathological gambling in Romanian teenagers. Minerva Medica. 93, 413-418.

Lupu, V., Todirita, I. R. (2013): Updates of the prevalence of problem gambling in Romanian teenagers. Journal of Gambling Studies. 29, 29-36.

Molinaro, S., Canale, N., Vieno, A., Lenzi, M., Siciliano, V., Gori, M. et al. (2014): Country and individual-level determinants of probable problematic gambling in adolescence: $\mathrm{A}$ multi-level cross-national comparison. Addiction. 109, 2089-2097.

Mravčík, V., Černý, J., Leštinová, Z., Chomynová, P., Grohmannová, K., Licehammerová, Š., Ziegler, A., Kocarevová, V. (2014): Gambling in the Czech Republic, Its Correlates and Consequences. Mravčík, V. (Eds.). Prag: Úřad vlády České republiky. http://www. drogy-info.cz/data/obj_files/1619/706/GAMBLING\%20REPORT_2013_EN_fin_web_fin. pdf (Retrieved 14.7.2016.)

National Research Council (1999): Pathological Gambling: A critical review. Washington, DC: National Academy Press. 
Nower, L., Blaszczynski, A. (2004): A Pathways Approach to Treating Youth Gamblers. In: Gupta, R., Derevensky, J.D. (Ed.): Gambling Problems in Youth - Theoretical and Applied Perspectives. New York: Kluwer Academic/Plenum Publishers. 284-303.

Olasson, D. T., Sigurdardottir, K. J., Smari, J. (2006): Prevalence estimates of gambling participation and problem gambling among 16-18-year-old students in Iceland: A comparison of the SOGS-RA and DSM-IV-MR-J. Journal of Gambling Studies. 22, 23-39.

Productivity Commission (1999): Australia's Gambling Industries Inquiry Report. Australia's Government Productivity Commission. http://www.pc.gov.au/inquiries/completed/ gambling/report (Retrieved 5.6.2016.)

Puharić, Z., Kudumija Sljepčević, M., Badrov, T., Petričević, N. (2016): Gambling among Teenagers in Bjelovar-Bilogora County (Croatia). Alcoholism and Psychiatry Research. 52, 5-16.

Rahman, A. S., Pilver, C. E., Desai, R. A., Steinberg, M. A., Rugle, L., Krishnan-Sarin, S., Potenza, M. N. (2012): The relationship between age of gambling onset and adolescent problematic gambling severity. Journal of psychiatric research. 46 (5), 675-683.

Raylu, N. i Oei, T.P. (2002): Pathological gambling. A comprehensive review. Clinical Psychology Review. 22 (7), 1009-1070.

Ricijaš, N., Dodig, D., Huić, A., Kranželić, V. (2011): Navike i obilježja kockanja adolescenata u urbanim sredinama - izvještaj o rezultatima istraživanja [Habits and characteristics of adolescent gambling in urban areas. A report on research results]. https://bib.irb. hr/prikazi-rad?\&rad=654654 (Retrieved 15.4.2016.)

Ricijaš, N., Dodig Hundrić, D., Huić, A. (2016). Predictors of adverse gambling related consequences among adolescent boys. Children and youth services review. 67, 168174.

Ricijaš, N., Dodig Hundrić, D., Kranželić, V. (2015): Sportsko klađenje i druga rizična ponašanja hrvatskih srednjoškolaca [Sports betting and other risk behaviour among croatian high-school students]. Hrvatska revija za rehabilitacijska istraživanja. 15 (2), 41-56.

Rossow, I., Molde, H. (2006): Chasing the criteria: Comparing SOGS-RA and the Lie/Bet screen to assess prevalence of problem gambling and 'at-risk' gambling among adolescents. Journal of Gambling Issues. 18, 57-71.

Shaffer, H.J., Hall, M.M. (1996): Estimating the prevalence of adolescent gambling disorders: A quantitative synthesis and guide toward standard gambling nomenclature. Journal of Gambling Studies. 12 (2), 193-214.

Shaffer, H.J., LaBrie, R., Scanlan, K.M., Cummings, T.N. (1994): Pathological gambling among adolescents: Massachusetts gambling screen. Journal of Gambling Studies. 10 (4), 339-362.

Shead, N. W., Derevensky, J. L., Gupta, R. (2010): Risk and protective factors associated with youth problem gambling. International Journal of Adolescent Medicine and Health. 22 (1), 39-58.

Skokauskas, N. (2009): Lithuania. U: Meyer G., Hayer T., Griffiths MD. (eds.). Problem Gaming in Europe: Challenges, prevention, and interventions. New York, NY: Springer. 173-188.

Sproston, K., Erens, B., Orford, J. (2000): Gambling Behaviour in Britain: Results from the British Gambling Prevalence Survey http://www.gamblingcommission.gov.uk/pdf/ 
Neven Ricijaš, Dora Dodig Hundrić, Aleksandra Huić, Valentina Kranželić: Youth gambling in Croatia...

\section{Gambling\%20behaviour\%20in\%20Britian\%20results\%20from\%20the\%20BGPS\%20 2000\%20-\%20Jun\%202007.pdf (Retrieved 15.7.2016.)}

Steinberg, L. (2007): Risk Taking in Adolescence: New Perspectives from Brain and Behavioral Science. Current Directions in Psychological Science. 16 (2), 55-59.

Steinberg, L. (2008): A social neuroscience perspective on adolescent risk taking. Development Review. 28 (1), 78-106.

Steinberg, L. (2010): A Dual System Model of Adolescent Risk-Taking. Developmental Psychobiology. 52 (3), 216-224.

Stuhldreher, W.L., Stuhldreher, T.J., Forrest, K.Y-Z. (2007): Gambling as an emerging Health Problem on Campus. Journal of American College Health. 56 (1), 75-83.

Tozzi, L., Akre, C., Fleury-Schubert, A., Suris, J. (2013): Gambling among youths in Switzerland and its association with other addictive behaviours: A population-based study. Swiss Medical Weekly; 143:w13768. http://www.smw.ch/content/smw-2013-13768/ (Retrieved 12.7.2016.)

Tremblay, J., Stinchfield, R., Wiebe, J., Wynne, H. (2010): Canadian Adolescent Gambling Inventory (CAGI) Phase III Final Report. Submitted to the Canadian Centre on Substance Abuse and the Interprovincial Consortium on Gambling Research.

Villella, C., Martinotti, G., Di Nicola, M., Cassano, M., La Torre, G., Gliubizzi, M.D., Messeri, I., Petruccelli, F., Bria, P., Janiri, L., Conte, G. (2011): Behavioural addictions in adolescents and young adults: results from prevalence study. Journal of Gambling Studies. 27 (2), 203-214.

Volberg, R.A., Gupta, R., Griffiths, M.D., Olason, D.T., Delfabbro, P. (2010): An international perspective on youth gambling prevalence studies. International Journal of Adolescent Medicine and Health. 22 (1), 3-38.

Welte, J. W., Barnes, G. M., Tidwell, M. C. O., Hoffman, J. H. (2008): The prevalence of problem gambling among US adolescents and young adults: Results from a national survey. Journal of Gambling Studies. 24, 119-133.

Welte, J.W., Barnes, G.M., Tidwell, M.O., Hoffman, J.H. (2009): Legal Gambling Availability and Problem Gambling Among Adolescents and Young Adults. International Journal of Gambling Studies. 9 (2), 89-99.

Winters, K.C., Stinchfield, R., Fulkerson, J. (1993): Patterns and characteristics of adolescent gambling. Journal of Gambling Studies. 9, 371-386.

Zakon o elektroničkim medijima [Electronic media act], Narodne Novine 153/09, 84/11, 94/13, 136/13.

Zakon o igrama na sreću [Games of Chance Act], Narodne Novine 87/09, 35/13, 158/13, 41/14, $143 / 14$. 